\title{
PEMANFAATAN VIDEO TUTORIAL (DEMONSTRASI) PADA PEMBELAJARAN PCKI DI MASA PANDEMI COVID-19
}

\author{
Nani Nurwati ${ }^{1}$, Heni Purwanti ${ }^{2}$ \\ Guru Kuliner SMK N 4 Yogyakarta \\ email: 025nene@gmail.com ${ }^{1}$,henipurwanti_smkn4@yahoo.com ${ }^{2}$
}

\begin{abstract}
ABSTRAK
Penelitian ini bertujuan untuk memaksimalkan pembelajaran siswa kelas XII, mata pelajaran PCKI (Pembuatan Cake dan Kue Indonesia) pada siswa kelas XII Kuliner 3, SMK Negeri 4 Yogyakarta, dengan materi praktik menghias cake pada acara perkawinan di masa pandemi Covid-19 melalui video tutorial demonstrasi. Strategi pengumpulan data yang digunakan adalah deskriptif kualitatif dengan memanfaatkan data kualitatif yang kemudian dijabarkan secara deskriptif. Menghias cake untuk acara perkawinan membutuhkan ketelitian, ketrampilan, dan kreativitas terutama pada saat mengapilkasikan butter cream, membuat bentuk hiasan dengan butter cream, memilih warna butter cream untuk hiasan, dan memilih ornamen untuk meningkatkan penampilan cake. Hasil penelitian menunjukkan bahwa pembelajaran praktik menghias cake untuk acara perkawinan dengan memanfaatkan video tutorial demonstrasi berdampak positif bagi siswa, ditunjukkan dengan pengumpulan tugas siswa yang tepat waktu, antusias serta semangat siswa dalam berdiskusi dan bertanya kepada guru saat mendapatkan kesulitan. Dari hasil foto praktek yang dikirimkan oleh siswa dapat dilihat bahwa dengan memanfaatkan video tutorial demonstrasi siswa dapat menggali potensi dan kreativitas sehingga meningkatkan pengetahuan dan keterampilan dan pada akhirnya berpengaruh pada hasil belajar siswa.

Kata kunci : acara perkawinan, , demonstrasi, menghias cake, pembelajaran praktik
\end{abstract}




\section{PENDAHULUAN}

Dunia pendidikan di Indonesia saat ini sedang di uji dengan adanya pandemi suatu virus yaitu Coronavirus Diseases 2019 (Covid-19). Covid-19 mulai pada Desember 2019 yang terjadi di Wuhan, China yang kemudian menyebar ke seluruh dunia dan Indonesia sebagai salah satu negara yang terdampak Covid-19 tersebut dengan ditemukan pasien Covid-19 pada bulan Maret 2020. Gejala umum seseorang terinfeksi virus Covid-19 adalah demam $37^{\circ} \mathrm{C}$ ke atas, sesak napas, batuk, dan hilang indera penciumannya. Pada tanggal 30 Januari 2020 WHO telah menetapkan pandemi Covid-19 ini sebagai kedaruratan kesehatan masyarakat yang meresahkan dunia. Dan sejak ditetapkan, kondisi pandemi ini memberikan dampak yang begitu banyak dari segala aspek kehidupan. Mulai dari perekonomian, sosial, pariwisata hingga pendidikan (Noftalina, 2020).

Kebijakan social distancing maupun physical distancing guna meminimalisir penyebaran Covid-19 mendorong semua elemen pendidikan untuk mengaktifkan kelas meskipun sekolah tutup. Penutupan sekolah menjadi langkah paling efektif untuk meminimalisir penyebaran wabah pada kluster perkantoran dan sekolah yang melibatkan siswa. Pada pandemi Covid-19 mendorong pelaksanan pembelajaran di sekolah yang semula tatap muka langung dengan guru menjadi pembelajaran jarak jauh atau online. Pembelajaran tatap muka yang awalnya melibatkan peserta didik dengan guru, dengan pembelajaran online melibatkan peserta didik, guru, dan orang tua sebagai kontrol pembelajaran dari rumah (BDR). Pada masa pandemi pembelajaran tetap harus berlangsung meskipun sekolah ditutup untuk mengurangi penyebaran wabah Covid-19. Pembelajaran online telah terjadi hampir diseluruh dunia selama pandemi Covid19. Guru dalam melaksanakan pembelajaran jarak jauh ini belum maksimal dalam mengkolaborasikan berbagai media pembelajaran seperti Whatsapp, Telegram, Youtube, Google Classrom, Google Drive, Google Mail, Google Meet Blog, Zoom, Learning Management System, dan sebagainya. Platform tersebut diharapkan dapat mendukung proses pembelajaran, diskusi dan berinteraksi dengan siswa, melakukan transfer pengetahuan secara online.

Pada Sekolah Menengah Kejuruan (SMK) pembelajaran praktik tetap harus diberikan meskipun siswa berada di rumah, hal ini dikeranakan siswa SMK harus 
memiliki keterampilan yang dapat meningkatkan kreativitas dan aktivitas siswa. meskipun pembelajran online siswa juga melakukan pembelajaran praktek yang dilakukan di rumah masing-masing. Di Program keahlian kuliner terdapat mata pelajaran Produk Cake dan Kue Indonesia (PCKI) dipelajari oleh peserta didik saat duduk di kelas XI dan kelas XII. Salah kompetensi dasar PCKI kelas XII yang harus dikuasai peserta didik adalah mengalisis hasil bahan peghias kue, menganalissi ornamen kue, mengalisis gateaux, torten, manganalisis cake ulang tahun, mengevaluasi cake perkawinan, dan mengevaluasi spesial cake. Mata pelajaran ini diajarkan oleh guru pengampu selama 8 jam pelajaran. Maksud diberikannya kompetensi dasar ini adalah agar peserta didik mampu dan terampil dalam memilih bahan menghias kue, memilih ornamen-ornamen untuk hiasan kue, serta terampil mempraktikkan seni menghias kue tart untuk acara khusus, seperti acara ulang tahun, acara kelahiran, acara pernikahan, hari raya, dan lainlain.

Keterlibatan siswa saat berlangsungnya proses pembelajaran praktek adalah siswa aktif mengikuti pembelajaran online, mendengarkan penjelasan guru, tanya jawab, dan sebagainya. (Sardiman, 1986), menyatakan bahwa setiap orang yang belajar harus aktif sendiri, sehingga proses pembelajaran tidak akan terjadi tanpa ada aktivitas.. Aktivitas dalam pembelajaran praktik dapat meningkatkan kemampuan dan keaktifan peserta didik dalam mengaplikasikan pengetahuan dan keterampilan yang diperolehnya. Salah satu model pembelajaran yang dapat mengaktifkan siswa sehingga dapat menggali kreativitas siswa adalah dilaksanakan pembelajaran teori dengan metode pembelajaran demonstrasi (Purwanti, 2021).

Menurut (Syah, 2010), metode demonstrasi adalah metode mengajar dengan cara memperagakan barang, kejadian, aturan, dan urutan melakukan suatu kegiatan baik secara langsung maupun melalui penggunaan media pengajaran yang relevan dengan pokok bahasan atau materi yang sedang disajikan. Pembelajaran dengan motode demonstrasi guru tidak hanya menyampaikan materi kepada siswa, tetapi materi tersebut dapat diaplikasikan dengan media berupa alat bantu atau peraga, sehingga siswa dapat termotivasi dan aktif dalam belajar. Salah satu metode pembelajaran demontrasi pada pembelajaran online 
dapat di lakukan yaitu dengan memberikan materi dalam bentuk rekaman video atau audiovisual (Noftalina, 2020). Pembelajaran pada mata pelajaran PCKI ini sebagaian materinya adalah melakukan pebelajaran praktek sehingga menjadikan tantangan bagi guru dan peserta didik melakukan praktek dari rumah dengan pembelajaran audivisual melalui video tutorial.

(Kustandi \& Stjipto, 2013), menyatakan video adalah alat yang dapat menyajikan informasi, memaparkan proses, menjelaskan konsep-konsep yang rumit, mengajarkan keterampilan, menyingkat atau memperlambat waktu dan mempengaruhi sikap. Sedangkan menurut (AL-Firdaus, 2010), mengatakan bahwa video atau film adalah rangkaian banyak frame gambar yang diputar secara cepat. Video adalah sebuah gambar hidup yang ditayangkan lewat layar yang mampu menyajikan informasi dan menjelaskan konsep-konsep yang rumit yang bahkan tidak mampu untuk ditangkap oleh indra manusia jika dilihat prosesnya secara langsung atau dengan kasat mata, (Utomo \& Ratnawati, 2018). Berdasarkan pengertian di atas, maka video tutorial adalah rangkaian gambar yang menyajikan informasi untuk memaparkan konsep-konsep dari orang yang ahli kepada seseorang sehingga mampu mempengaruhi, menambah pengetahuan, dan memahami topik yang sedang di pelajari.

Tujuan utama pada penelitian ini adalah untuk mendeskripsikan pemanfaatan video tutorial demonstrasi pada pembelajaran PCKI dimasa pandemi covid'19. Sedangkan rumusan masalah yang diajukan adalah apakah pembelajaran melalui video tutorial demontrasi dapat mengoptimalkan kemampuan kreativitas siswa selama pembelajaran online dimasa pandemi covid '19. Adapun manfaat yang diharapkan adalah untuk memperbaiki kualitas proses pembelajaran, yang pada akhirnya juga akan memperbaiki hasil belajar siswa terutama pada pembelajaran online dimasa pandeni covid'19.

\section{METODE PENELITIAN}

Metode penelitian ini menggunakan deskiptif kualitatif berdasarkan pengamatan dari objek yang diteliti pada saat berlangsungnya pembelajaran PCKI kelas XII kuliner 3, selama pandemi Covid-19. Deskriptif kualitatif bersifat menggambarkan, memaparkan, dan menguraikan objek yang diteliti (Arikunto, 2006). Penelitian ini dilaksanakan pada saat pembelajaran PCKI selama masa 
pandemi Covid-19 secara online baik pembelajaran teori maupun pembelajaran praktik. Pembelajaran PCKI kelas XII Kuliner 3 dilaksanakan setiap hari Kamis selama 8 jam pelajaran dari 07.30-14.15. Sasaran penelitian ini adalah siswa kelas XII Kuliner 3 (sebanyak 29 siswa).

Prosedur penelitian ini menggunakan beberapa langkah penelitian. Langkahlangkah penelitian ini sesuai dengan tahapan guru dan peserta didik dalam melaksankan proses pembelajaran. Prosedur penelitian yang dilakukan adalah : (1) Peserta didik melaksanakan pembelajaran dari rumah secara online. Guru memberikan infromasi pembelajaran melalui group whatsapp mata pelajaran, peserta didik menyimak semua informasi yang diberikan oleh guru meliputi materi pembelajaran, lembar kerja praktek, dan tata tertib pelaksanaan pembelajaran. (2) Media pembelajaran yang digunakan adalah menggunakan group whatsapp kelas, Google Classroom, dan Youtube. Materi pembelajaran disampaikan guru dengan media powerpoint dan berupa handout yang diberikan guru kepada siswa menggunakan media Google Classroom. Untuk pembelajaran praktek siswa menggunakan video tutorial yang diperoleh dari youtube, (3) Penugasan pembelajaran praktek pembelajaran PCKI selama pembelajaran online dilaksanakn untuk memperoleh nilai keterampilan peserta didik. Hasil praktek dapat dikirmkan melalui Google Classroom. (4) Peralatan dan bahan praktek yang digunakan oleh peserta didik disediakan mandiri oleh peserta didik itu sendiri. Peralatan yang dibutuhkan adalah spuit, pipping bag, bowl, dan spatula. Bahan utama adalah sponge cake, butter cream, pewarna, dan ormanent cake. (5) Perserta didik melaksanakan praktek dari rumah secara mandiri dengan bimbingan guru melalui whatsapp group. Peserta didik mencari video tutorial di youtube sebelum melaksanakan praktek, sebagai panduan dalam melaksanakan praktek. Video tutorial boleh lebih dari satu video, sebagai referensi siswa dalam melaksakan praktek. Guru dan peserta didik melakukan komunikasi dan konsultasi melalui whatsapp group kelas atau melalui whatsapp langsung dengan guru. (6) Setelah selesai melaksanakan praktek siswa mendokumentasikan hasil pekerjaannya berupa foto-foto. Foto hasil praktek dapat di unggah melalui Google Classroom oleh siswa.

\section{HASIL DAN PEMBAHASAN}


Pembelajaran menghias cake dilaksanakan sebanyak dua kali pertemuan pada pembelajaran online. Sebelum melakukan pembelajaran guru membuat perencanaan pembelajaran yang berupa rencana program pembelajaran (RPP). RPP yang merupakan pegangan bagi guru dalam melaksanakan pembelajaran baik di kelas, ruang praktek (laboratorium komputer) dan atau lapangan untuk setiap kompetensi dasar (Nazarudin, 2007). Selain membuat RPP guru juga menyiapkan media pembelajaran yang berupa ringkasan materi pada powerpoint, mencari video tutorial tentang tutorial menghias cake perkawinan di Youtube, menyiapkan jobsheet praktek, membuat format penilaian yang terdiri dari penialaian pengetahuan dengan soal pilihan ganda, penilaian keterampilan dari kegiatan praktek yang dilakukan siswa dari rumah, penilaian sikap dari pengamatan selama mengikuti proses pembelajaran. Selain itu guru juga membuat indikator penilaian hasil praktek membuat cake perkawinan, sebagai berikut :

Tabel 1. Indikator Penilaian Praktek PCKI Menghias Cake

\begin{tabular}{clc}
\hline No & \multicolumn{1}{c}{ Uraian } & Skor \\
\hline 1. & Ketepatan waktu penyelesaian praktek & 20 \\
2. & Keaktifan diskusi & 20 \\
3. & Kesesuaian tema & 20 \\
4. & Perpaduan warna & 20 \\
5. & Kesesuaian hiasan/ornamen cake & 20 \\
\hline
\end{tabular}

Berdasar tabel 1, indikator penilaian praktek PCKI menghias cake untuk acara perkawinan dapat dilihat bahwa skor maksimal adalah 100, dan KKM yang ditetapkan pada mata pelajaran PCKI adalah 75. Dari 5 macam indikator penilaian praktek diatas masing-masing mempunyai bobot skor 20, dan penilaian dilakukan dalam kelompok. Sehingga untuk nilai praktek, setiap siswa dalam satu kelompok akan mempunyai nilai yang sama maka setiap kelompok wajib mengirimkan foto seluruh siswa dalam satu kelompok sedang melaksanakan praktek membuat cake perkawinan.

Pada tahap pelakasanaan proses pembelajaran secara online menghias cake adalah guru mempersiapkan siswa dengan menyapa siswa melalui whatsapp group bahwa pembelajaran akan dimulai. Selanjutnya guru akan mengarahkan siswa untuk membuka google classroom mata pelajaran PCKI. Dalam google 
classroom guru akan menginformasikan tentang kompetensi dasar yang akan dipelajari, tujuan pembelajaran, materi pembelajaran tentang menghias cake untuk acara perkawinan. Guru meminta siswa untuk melakukan presensi di kolom yang dudah disediakan di google classroom dengan menuliskan nama dan nomor absen. Setelah melakukan presensi guru memastikan semua siswa untuk membaca dan mempelajari materi pembelajaran yang disajikan oleh guru dalam bentuk powerpoint berupa ringkasan teori menghias cake untuk acara perkawainan, peralatan, dan ornamen digunakan. Guru dan siswa melakukan diskusi melalui whatsapp group kelas, melalui whatsapp pribadi guru dan siswa, serta melalui kolom komentar google classroom.

Pada pertemuan pertama ini akhiri dengan memberikan soal evaluasi, siswa diminta mengerjakan 10 soal pilihan ganda dan siswa diminta membuat perencanaan praktek menghias cake untuk acara perkawinan secara berkelompok, setiap kelompok terdiri dari 4 siswa. Pada pelaksanan metode demonstrasi siswa diminta mencari video tutorial tentang cara menghias cake untuk acara perkawinan. Siswa boleh mencari video tutorial di youtube sebanyak-banyaknya agar siswa dapat memperoleh gambaran dan menambah kreativitas siswa dalam melaksanakan praktek. Pada penugasan ini guru juga membagikan langkah kerja praktek sehingga siswa dapat mengetahui langkah-langkah apa yang akan dilakukan saat praktek menghias cake pada pertemuan berikutnya. Pelaksanaan pembelajaran dengan metode demontrasi ini bertujuan agar siswa dapat berpikir kreatif, inovatif, dan memberikan aktivitas siswa mendapatkan gambaran secara nyata dari teori yang telah dipelajari sehingga dapat meningkatkan hasil belajar siswa.

Langkah-langkah dalam kegiatan pembelajaran dengan metode demonstrasi adalah sebagai berikut: (1) Guru membuka pembelajaran di whatsapp group untuk menyiapkan siswa (2) Guru memberikan penjelasan tentang materi dan langkah kerja praktek mengias cake untuk acara perkawinan di google classroom. (3) Guru memberikan beberapa video tutorial demonstrasi tentang praktek menghias cake untuk acara perkawinan. (4) Guru meminta siswa untuk mengamati dan mencermati video tutorial. (5) Guru meminta siswa membuat kelompok untuk mengerjakan praktek menghias cake untuk acara perkawinan. (6) Bersama 
kelompoknya, siswa mendemonstrasikan tugas yang diberikan oleh guru (menanamkan nilai berpikir kreatif dan sistematis). (7) Bersama dengan kelompoknya siswa mengirimkan foto hasil praktek ke google classroom. (8) Guru memberikan evaluasi terhadap hasil praktek siswa.

Pada pertemuan kedua guru memberikan beberapa video tutorial cara mengias cake untuk acara perkawinan melalui media youtube. Guru memberikan beberapa contoh link video tutorial tentang menghias cake untuk acara perkawinan, siswa diminta untuk melihat dan mencermati video tersebut dengan alamat :

1. https://youtu.be/ZkAlAycgeAc

2. https://youtu.be/yvWhCG4tiVw

3. https://youtu.be/TTAAMedl.9wM

4. https://youtu.be/jWWfDv5TXQ

5. https://youtu.be/1hmG41Y5mgw

6. https://youtu.be/eUw5MnlzCdY

Namun, pada pertemuan sebelumnya guru juga menginformasikan kepada peserta didik untuk mencari beberapa video tutorial menghias cake sebagai tambahan informasi. Setelah siswa melihat dan mengamati beberapa video tutorial demonstrasi menghias cake di youtube, siswa menjadi antusias untuk mencoba dan segera mempraktekkan menghias cake. Siswa sudah tidak sabar untuk segera mendemontrasikan menghias cake dengan peralatan dan bahan yang sudah disiapkan di rumah secara berkelompok. Namun, sebelum melakukan praktek guru memberikan kesempatan kepada siswa untuk melakukan diskusi melalui whatsapp group maupun melalui whatsapp pribadi tentang video demontrasi yang diamati. Jika sudah tidak ada pertanyaan dari siswa, guru mempersilahkan siswa untuk mempersiapkan peralatan dan bahan untuk praktek.

Proses pembelajaran berikutnya adalah siswa melakukan praktek menghias cake untuk acara perkawinan di secara berkelompok dengan ketentuan satu kelompok terdiri dari 4-5 orang siswa, sehingga di kelas XII Kuliner 3 yang terdiri dari 29 siswa terdapat 6 kelompok yang beranggotakan 4 siswa dan 1 kelompok yang beranggotakan 5 siswa. Praktek dilaksanakan di salah satu rumah siswa yang telah mereka sepakati. 
Hasil pelaksanan praktek menghias cake untuk acara perkawinan yang dibuat oleh siswa menunjukkan hasil hiasan cake yang berbeda-beda dan bervasiasi dalam menghiasnya. Hal ini disebabkan siswa memiliki daya kreativitas masing-masing dan siswa banyak memperoleh informasi dari video tutorial dari youtube yang membantu siswa dalam mendemonstrasikan menghias cake. Praktek menghias cake membuat siswa antusias dalam mengikuti pembelajaran hal ini dapat dilihat dari foto hasil praktek siswa yang dikumpulkan siswa secara berkelompok tepat waktu. Pembelajaran praktek dianggap pembelajaran yang menyenangkan bagi siswa, karena siswa dapat mengekplorasi apa yang menjadi keinginan siswa, sehingga siswa dapat menyampaikan gagasannya dalam bentuk presentasi sebuah hidangan yang menarik.

Dari hasil praktek menghias cake acara perkawinan yang telah dilakukan siswa, diperoleh hasil penilaian yang dilakukan oleh guru seperti pada tabel 2 .

Tabel 2. Hasil Penilaian Praktek Menghias Cake Acara Perkawinan

\begin{tabular}{ccc}
\hline No & Kelompok & Nilai \\
\hline 1. & Kelompok 1 & 87 \\
2. & Kelompok 2 & 88 \\
3. & Kelompok 3 & 87 \\
4. & Kelompok 4 & 86 \\
5. & Kelompok 5 & 90 \\
6. & Kelompok 6 & 87 \\
7. & Kelompok 7 & 86
\end{tabular}

Berdasarkan hasil tabel 2 dapat dilihat bahwa hasil penilaian praktek siswa sudah menunjukkan nilai di atas KKM dan semuanya tuntas. Satu kelompok mendapatkan nilai tertinggi 90 yaitu kelompok 5, satu kelompok mendapatkan nilai 88 yaitu kelompok 2, dan tiga kolompok mendapatkan nilai 87 yaitu kelompok 1 dan 6, dua kelompok mendapatkan nilai terendah 86 yaitu kelompok 3 dan kelompok 7 . Hiasan cake untuk acara perkawinan biasanya dibuat lebih mewah dan dengan tampilan seni yang tinggi daripada cake untuk acara ulang tahun. Warna warna yang digunakan juga lebih berwarna warni / bervariasi. Untuk tulisan dapat dibuat dengan menggunakan butter cream seperti contoh kue ulang tahun atau dapat juga menggunakan tulisan yang terbuat dari bahan yang tidak dapat dimakan (unedible) sebagai penghias agar lebih terlihat menarik. Cake dihias dengan butter cream yang menambahkan rasa manis dan lembut pada kue. 
Peserta didik mengaplikasikan penggunaan butter cream untuk menutupi seluruh permukaan kue sebelum dihias

Kelompok 1, membuat hiasan cake acara khusus perkawinan dengan menggunakan warna cerah. Bahan dasar penghias kue menggunakna butter cream yang dibagi menjadi beberapa warna sesuai dengan kebutuhannya. Berikut hasil menghias cake kelompok 1 .

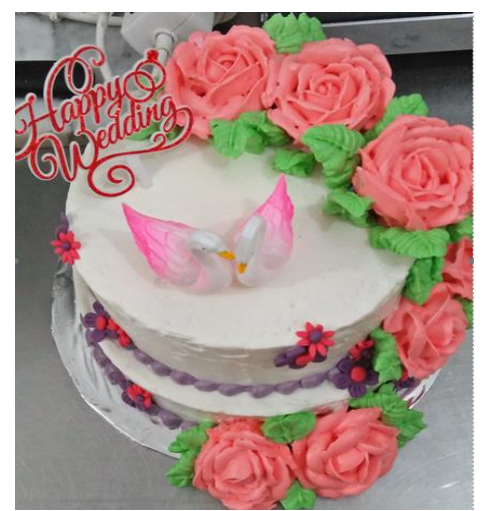

Gambar 1. Cake kelompok 1

Butter cream untuk menutup cake dibuat dengan warna dasar putih yang memberikan kesan bersih, dengan menyisakan bagian kosong yang dapat ditulisi ucapan selamat. Butter cream dengan warna pastel merah muda dipilih untuk membuat hiasan bunga mawar, pewarnaan yang tidak terlalu mencolok membuat nyaman dilihat. Penempatan hiasan bunga mawar dari bawah cake merambat sampai di atas cake menjadikan cake lebih meriah dengan banyak bunga. Hiasan daun di bawah bunga juga tidak lupa diberikan agar memberikan kesan bahwa bunga tersebut hidup. Bunga bunga kecil dengan warna mencolok untuk mengisi daerah yang masih kosong agar cake tersebut lebih menarik. Ornamen sepasang angsa diberikan sebagai simbol pasangan yang sedang berbahagia, romantis, hangat, dan penuh dengan cinta, sedangkan ornamen tulisan happy wedding yang menggambarkan cake tersebut sebagai salah satu simbol acara perkawinan. Koreksi untuk kelompok satu adalah bagian atas cake masih ada ruang kosong di sekitar angsa, sebaiknya di isi hiasan dengan butter cream dengan warna yang mencolok, misalnya hiasan bunga kecil, atau rumput.

Kelompok 2, membuat cake untuk acara perkawinan dengan menggabungkan dua cake. Cake bagian bawah dibuat lebih besar dan cake bagian atas dibuat lebih kecil. Bahan penghias utama menggunakan warna dasar butter 
cream warna putih yang diaplikasikan ke seluruh permukaan cake. Berikut hasil menghias cake kelompok 2.

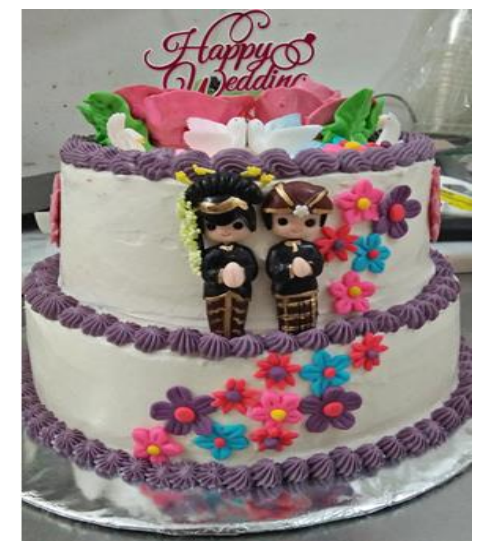

Gambar 2. Cake Kelompok 2

Dengan bantuan spuit cake dihias dengan bunga mawar dan bunga - bunga kecil yang dibuat dengan butter cream yang diberikan sedikit pewarna makanan agar terlihat cerah, sehingga menghasilkan bunga yang warna warni yang manarik perhatian. Hiasan bunga mawar besar berwarna merah muda pada bagian atas cake memberikan kesan meriah dan bahagia. Pinggir cake diberikan hiasan butter cream dengan warna cerah. Terdapat berbagai macam hiasan atau ornamen untuk menghias kue tart pernikahan agar tampah mewah. Ornamen tulisan happy wedding memberikan informasi bahwa cake tersebut untuk cake acara pernikahan. Ornamen sepasang angsa diberikan untuk menambah kesan romantis, bahagia, dan penuh cinta. Pada cake di atas dihiasi dengan ornamen sepasang pengantin dengan berbusana adat jawa, dan dikombinasikan dengan hiasan yang modern. Koreksi untuk kelompok dua adalah hiasan bunga kecil-kecil ditempatkan di bagian depan cake dengan jumlah yang banyak, ditambah ornamen sepsang pengantin, sehingga bagian depan cake terlihat terlalu ramai hiasannya. Sedangkan di bagain pinggir cake hanya butter cream polos belum ada hiasannya, hal ini menjadi kontras dengan bagian depan cake yang banyak hiasan dan bagian pinggir cake yang masih ada ruang kosong tidak ada hiasannya.

Kelompok 3, cake acara khusus perkawinan yang dibuat dengan butter cream sebagai bahan utama penutup cake. Warna dasar cake juga menggunakan warna dasar putih dipadukan dengan butter cream warna warni sebagai hiasannya. Berikut hasil menghias cake kelompok 3. 


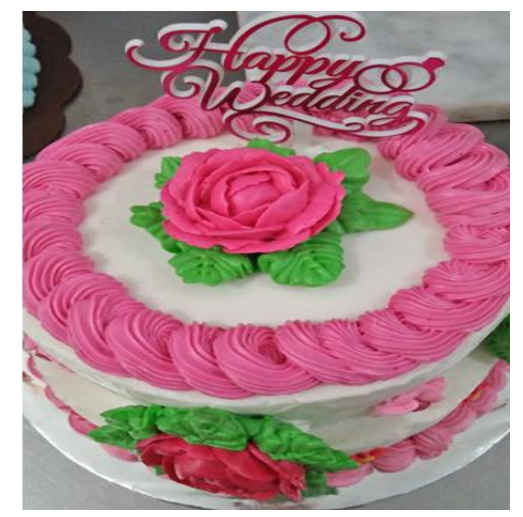

Gambar 3. Cake Kelompok 3

Hiasan cake dari kelompok 3 tampak sederhana dengan suasana warna merah muda yang mencolok menjadikan cake menjadi meriah. Butter cream warna putih diaplikasikan untuk menutupi seluruh bagian cake. Bagain pinggir dan atas cake di hias dengan satu buah bunga mawar besar untuk memberikan kesan meriah, cantik, dan tidak lupa memerikan hiasan daun warna hijau mencolok agar bunga terkesan hidup. Pinggir cake dihias dengan butter cream warna pink dengan bantuan spuit. Cake ini tidak menggunakan warna yang banyak, hanya menggunakan tiga warna sebagai kombinasi hiasan cake yaitu putih, merah muda, dan hijau. Ornamen yang bertuliskan happy wedding menunjukkan bahwa cake tersebut sebagai cake untuk acara pernikahan. Koreksi untuk kelompok 3 adalah kurangnya varaisi warna pada bagian atas cake, hiasan butter cream warna pink dan warna bunga mawar sebagai hiasan juga berwarna senada, sebaiknya warna dibedakan untuk menghasilkan hiasan yang lebih ceria, ceria, dan berwarna.

Kelompok 4 membuat hiasan cake dengan warna dasar butter cream untuk cake sama seperti kelompok lainnnya yaitu warna dasar putih. Hiasan bunga mawar dan diberikan daun hijau yang membuat bunga tersebut menjadi hidup, dan tampak nyata seperti bunga asli. Butter cream dibentuk menjadi bunga mawar diberikan di pinggir pinggir cake. Di kelompok 4 ini, bunga mawar besar banyak diberikan di pinggir, jadi pusat perhatian/center of interest berada di pinggir cake. . Berikut hasil menghias cake kelompok 4 


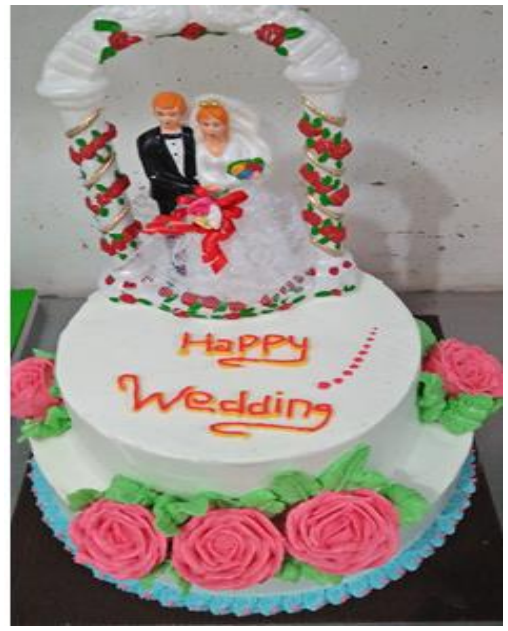

Gambar 4. Cake Kelompok 4

Bagian atas cake tidak diberikan hiasan dari butter cream melainkan diberikan ornamen yang berupa miniatur pernikahan berkonsep gaun internasional. Bagain atas cake sengaja diberikan ruang kosong agar di tengah terdapat ruang untuk menulis ucapan. Tulisan happy wedding ditulis menggunakan butter cream bukan menggunakan ornamen. Koreksi untuk kelompok 4 adalah pada bagian atas cake masih terlihat polos, meskipun sudah ada tulisan. Di sekitar tulisan happy wedding sebaiknya ditambahkan hiasan, misalnya bunga kecil. Dan ukuran tulisan happy wedding sebaiknya lebih kecil.

Kelompok 5 membuat hiasan cake dengan menggunakan bahan utam penghias butter cream dengan warna putih bagian bawah, dan bagian atas dengan butter cream berwarna merah muda sehingga membuat cake terkesan romantis. . Berikut hasil menghias cake kelompok 5.

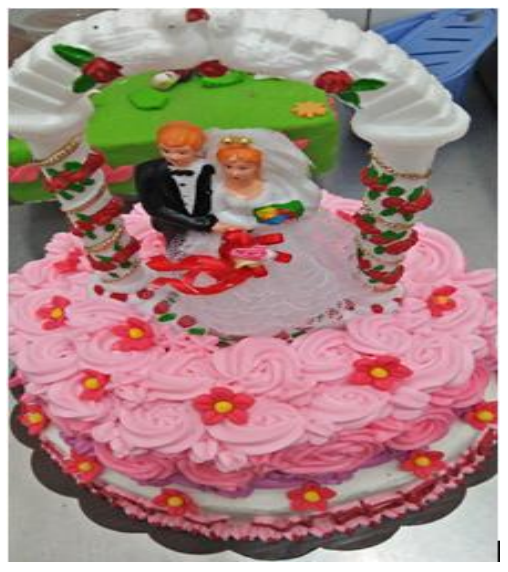

Gambar 5. Cake Kelompok 5 
Butter cream sebagai bahan penghias utama, dan bentuk bunga yang mendominasi dari hiasan kue. Warna butter cream selalu dibuat dengan wara cerah, sehingga orang yang melihat akan senatiasa merasa senang melihatnya dan merasa tidak bosan. Cake bagian bawah dengan butter cream warna dasar putih di hias dengan warna merah muda bagian pinggirnya, dan ditulisi dengan happy wedding yang menunjukkan bahwa kue tersebut untuk acara pernikahan. Cake bagian atas ditutup dengan butter cream warna merah muda dibentuk bunga bunga secara keseluruhan, dan dihiasi dengan bunga kecil-kecil warna merah kuning sehingga terlihat mencolok kontras dengan warna merah muda sehingga terlihat meriah dan mewah. Bentuk cake kelompok 5 di atas menggunakan ormanen sepasang pengantin dengan pakaian internasional. Kelompok 5 bentuk hiasan cakenya sudah bagus, variasi warna dalam menghias cake sudah bagus.

Kelompok 6 sama dengan kelompok yang lain menggunakan butter cream dengan warna dasar putih sebagai bahan penutup cake. Butter cream dibagi menjadi warna putih, merah muda, biru, ungu, merah, dan hijau. . Berikut hasil menghias cake kelompok 6.

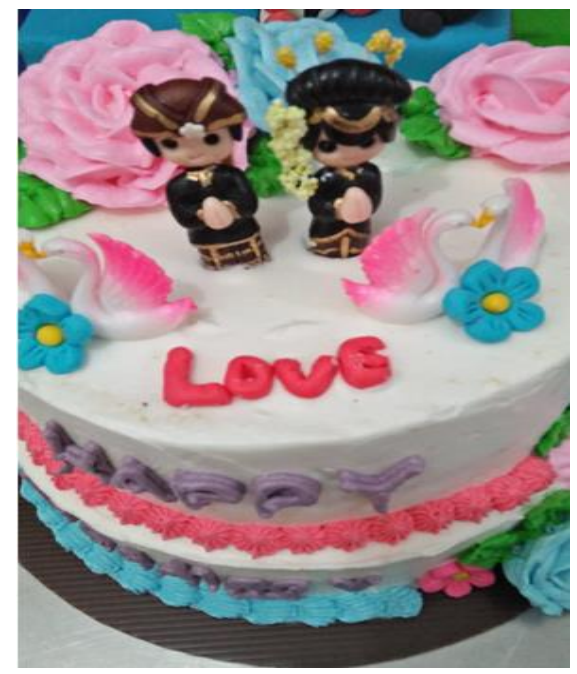

Gambar 6. Cake Kelompok 6

Warna warna cerah dipadukan oleh kelompok 6 sehingga warna hiasan cake terlihat meriah. Butter cream berbentuk bunga wawar warna merah mudan biru di bagian atas cake membuat tampak cantik cake tersebut. Tambahan ornamen sepasang pengantin tradisional jawa dan dua pasang angsa juga menambah kesan pesta yang meriah. Pada ruang kosong bagian atas di tulisi love yang bertujuan 
agar cake tersebut lebih bermakna sebagai ikatan cinta acara pernikahan. Koreksi pada kelompok 6 adalah dibagian pinggir sudah diberikan tulisan sebaiknya bagaian atas tidak pelu diberikan tulisan. Ornamen yang diberikan pada bagian atas cake juga terlalu banyak, sebab hiasan bunga mawar dari butter cream sudah menghiasi cake tersebut.

Kelompok 7 , sama dengan cake yang dibuat kelompok lain membuat hiasan cake dengan warna dasar butter cream warna putih. Hiasan bunga mawar warna merah muda dibagian pinggir dan atas cake sehingga membuat cake menjadi menarik. Tulisan happy wedding dibuat dengan butter cream berwarna ungu dan dipertegas dengan warna merah muda, tulisan tersebut menandakan cake untuk acara pernikahan. Berikut hasil menghias cake kelompok 7.

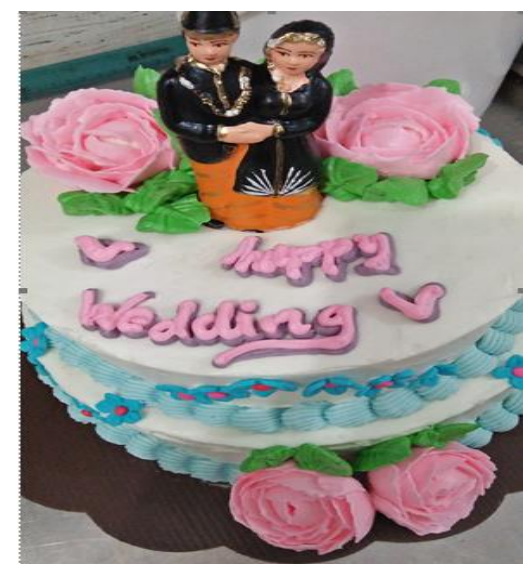

Gambar 7. Cake Kelompok 7

Ornamen sepasang pengantin menambah kemeriahan cake tersebut. Hiasan bunga-bunga kecil dari butter cream dengan warna biru muda pada bagian pinggir cake menambah cantik cake. Warna butter cream pada Cake kelompok 7 ini, cenderung menggunakan warna yang lembut, sehingga tampak kurang meriah disbanding cake dari kelompok yang lain. Koreksi untuk kelompok 7 adalah penggunaan warna tulisan senada dengan warna bunga, sebaiknya dibedakan sehingga ada kontras warna pada cake tersebut.

\section{KESIMPULAN}


Pembelajaran praktek siswa pada materi menghias cake untuk acara perkawinan dengan memanfaatkan video tutorial demonstrasi membuat siswa antusias dalam mengikuti pembelajaran sehingga dapat menumbuhkan sikap kreatifitas dan meningkatkan keterampilan siswa dalam menghias cake untuk acara perkawinan. Praktik siswa yang dilakukan secara berkelompok menumbuhkan sikap kerja sama diantara teman sejawat, berbagi ide, dan gotong royong dalam melakukan pemecahan masalah. Pembelajaran praktek dianggap siswa pelajaran yang menyenangkan dari pada pembelajaran teori hal ini dapat dilihat dari pengumpulan tugas untuk pembelajaran praktek siswa mengumpulkan tepat waktu, sedangkan tugas pembelajaran teori kadang siswa sering menunda pekerjaannya.

Pembelajara praktek yang dilakukan dirumah menumbuhkan ide kreatif anak terutama pada masa pandemi saat ini dimana guru tidak bisa langsung membimbing siswa di sekolah, namun siswa harus aktif belajar mandiri untuk memahami materi yang sedang dipelajari. Kreativitas siswa dapat dilihat dari hasil praktek siswa dalam menghias cake, dari hiasan yang digunakan siswa secara mandiri sudah dapat membuat hiasan berbentuk bunga mawar dari butter cream, siswa dapat memilih ornamen yang sesuai untuk cake acara khusus perkawinan, dan siswa tentu dapat memilih warna warni butter cream untuk menghias cake untuk acara perkawinan.

\section{DAFTAR PUSTAKA}

AL-Firdaus, I. (2010). Buku Lengkap Tuntunan Menjadi Kameramen Profesional. Buku Biru.

Arikunto, S. (2006). Metode Penelitian Kualitatif. Bumi Aksara.

Kustandi, C., \& Stjipto, B. (2013). Media Pembelajaran Manual dan Digital Edisi Kedua. Ghalia Indonesia.

Nazarudin. (2007). Manajemen Pembelajaran. Teras.

Noftalina, E. (2020). Efektivitas Metode Video Tutorial Dengan Demonstrasi Pembelajaran Mata Kuliah Kegawatdaruratan Maternal Neonatal Di Masa Pandemic Covid 19. Jurnal Ilmiah Umum Dan Kesehatan Aisyiyah, 5(2), 110-114. 
Purwanti, H. (2021). Pembelajaran Kreatif pada Praktik Pengolahan dan Penyajian Makanan Kontinental melalui Metode Demonstrasi. Ideguru: Jurnal Karya Ilmiah Guru, 6(2), 127-136. https://doi.org/10.51169/ideguru.v6i2.201

Sardiman. (1986). Interaksi dan Motivasi Belajar Mengajar. Rajawali Pers.

Syah, M. (2010). Psikologi Pendidikan. PT Remaja Rosdakarya.

Utomo, A. Y., \& Ratnawati, D. (2018). Pengembangan Video Tutorial Dalam Pembelajaran Sistem Pengapian Di Smk. Taman Vokasi, 6(1), 68. https://doi.org/10.30738/jtvok.v6i1.2839 